\title{
Corporate strategy, corporate capture: Food and alcohol industry lobbying and public health
}

\begin{abstract}
This article examines two industry sectors - those making and selling fast food and alcoholic beverages or associated products. We examine their role in influencing policy and decision making on the regulation of their products for health reasons. We argue that the food and alcohol industries engage in a very wide range of tactics and strategies to defend and indeed to promote their 'licence to operate'. We focus in on a specific component of these by examining public relations and lobbying strategies and their impacts on elite decision makers. We suggest that lobbying influence is a matter of both communication and action. We go on to outline the vertical and horizontal differentiation of lobbying strategies arguing that policy capture is the ultimate goal of lobbying, though influence is pursued by wide-ranging strategies to capture various arenas of decision making. We examine four key arenas; science, civil society, the media and policy, closing with an examination of two cases of the so-called 'partnership' model of governance.
\end{abstract}

Key words: alcohol industry, corporate power, food industry, lobbying, public relations

\section{Introduction}

This article examines the activities of the alcohol and food industries in attempting to resist meaningful progress on public health measures to tackle consumption related harms. We argue that lobbying is crucially important in this and that it is one of a variety of means that corporations have at their disposal to manage various social domains such as the media, science and civil society as well as most obviously policy. We argue that the management of these domains is a core function 
of corporate strategy and that lobbying conceived broadly is one key means for corporations to attempt to exert power and control in varying social domains. Our argument builds on the work of Farnsworth and his colleagues who apply to social policy the well known distinction between structural power (the power of investment decisions) and the power of corporate agency (the pursuit of influence over policy and politics) (Farnsworth, 2004, 2006; Farnsworth and Holden, 2006; Holden and Lee, 2009). However, we take this further in arguing the need to see questions of influence in the context of communication. By this we mean that communication is intrinsic to influence and cannot be separated from action and agency. Indeed we see the two as fundamentally connected by interests. This provides an approach that moves beyond traditional 'power structure' research.

To understand how influence works we draw upon work on the emergence of the neoliberal 'thought-collective' (Mirowski and Plehwe, 2009). This differs from previous accounts in that it explicitly incorporates ideas as well as structure in questions of 'influence'. However, we go beyond this in focusing on the practical role of ideas via communication, the concept which links structure with ideas and influence: in a phrase 'communicative agency' - a notion that undercuts poststructuralist and 'discursive' approaches and which ensures that ideas and communication take their proper intrinsic role in the analysis of power and legitimation as opposed to being tacked on or fore-grounded at the expense of both structural power and extra discursive action. We argue that focusing on the communicative agency involved is a valuable corrective to those approaches tending to emphasize only structure or 'discourse'. Our concept draws on elements of Habermas' theory of communicative action, specifically the notion that communication and debate are crucial (Habermas, 1984, 1987). However, it recognizes the limitations of the concept as applied to actually existing capitalism in which the basic consensus model envisaged by Habermas is crucially undermined by inequalities of communicative resources in the context of hegemonic processes - by ideological dissensus.

In our view lobbying is a matter of communicative agency as opposed to a matter of structural power, influence or 'discourse' and we discuss it in these terms throughout the article. Lobbying is an important dimension of policy processes in the UK and other Western nations, though it can often be ignored in the literature on policy and indeed in the wider social science literature. While there is an extensive literature on lobbying or 'interest representation', the communicative aspect of lobbying is 
often missing. For us lobbying (and public relations) are fundamentally matters of communicative agency. Our account of lobbying emphasizes corporate strategy and its coherence (though obviously there are often internal tensions within corporations). Though we concentrate on a specific set of tactics in this article, we always see these in the wider context of overall corporate strategy, which, we argue, is the best way to understand corporate agency and consequently power. In this paper we suggest that the significance of communicative agency is illustrated by the empirical evidence that corporations actively engage in attempting to dominate the information environment, so they can significantly affect decision making. We refer to this as capture, but it is important to understand that this is a question not only of 'policy' capture but of capturing a wide range of arenas of debate and decision making either because these are seen as intrinsically important or because they are useful for activities in other arenas (see Miller and Mooney, this volume).

\section{Food and alcohol}

We have chosen to focus on food and alcohol, for two main reasons. Firstly because they are both issues with strong science based components and this allows us to illustrate the importance of the management of science in social policy; secondly because they are a strong and growing focus for policy discussions at a range of levels, from the national to the global (Nestle, 2003; Hawkes, 2006).

Taking the example of food and obesity first we can note that in 2004 the World Health Organisation announced that the scale of obesity worldwide meant that it had overtaken hunger as the world's principal nutritional problem, even in some developing countries (WHO, 2004). Adult onset diabetes has been renamed type two diabetes because it no longer just affects adults, children as young as eight are being diagnosed with the condition (Brownell and Warner, 2009). In the UK the Department of Health states: 'Rising levels of obesity in the UK mean that 90 per cent of today's children will be overweight and at risk from serious diseases by 2050 , costing the NHS an estimated $£ 50$ billion' (Nicholson, 2009: 12).

WHO figures show that alcohol over-consumption is a significant public health problem in Europe; it is the third biggest killer after tobacco and hypertension, one in ten deaths are attributable to alcohol in Europe (Anderson and Baumberg, 2006). Young people are particularly 
vulnerable with one in four deaths in males aged 15-29 years in Europe attributable to alcohol and 55,000 young people dying as a result of alcohol in 1999 (Anderson and Baumberg, 2006; Beaglehole and Bonita, 2009; Rhem et al., 2004, 2009).

Alcohol and food share a number of similarities as issues but it is also clear that there are differences. First it can be noted that alcohol is similar to tobacco in that it is harmful to health and is also subject to regulations regarding its sale and distribution. There are social benefits to consuming alcohol that differentiate it from tobacco and tobacco has been stigmatized in a way that alcohol and food cannot be. Food is easily distinguished from tobacco and alcohol as an essential part of nutrition. Although a growing area of concern in social policy circles, it is not subject to control policies in the same way alcohol and tobacco are. What each of the three has in common is that the industries that produce alcohol, tobacco and junk food blame the consumer and their individual choices for any adverse health effects resulting from consumption.

There are specific issues in understanding how alcohol and food risks are dealt with in comparison to other issues. However, it is our contention that the model of the interaction between business and social policy that we outline applies equally well to other areas of social policy.

\section{Neoliberalism, globalization and levels of governance}

Corporate led globalization has resulted in more stratified decision making both devolving it down and coordinating it up. The neoliberal era ushers in a new political geography of governance. This does not necessarily mean that the nation state has 'lost' power, but rather that the venues of decision making have diversified (Kooiman, 1999; Rhodes, 2000). Consequently it is no longer enough to take the nation state as the primary or only unit of analysis. We need to pay close attention to the vertical differentiation of corporate agency at the local, national and supranational level. Stratification occurs horizontally as well, so that decision making and power flow out from the state to private actors. Private actors (and some others) are invited into the state to make policy. It is no longer enough to think about corporations only as attempting to influence policy. In reality much decision-making power has been directly devolved to them while corporations are increasingly 'internal' to the state. We will explore this in some detail towards the end of this article in taking two cases of 'partnership' governance. 
At each level of governance, lobbyists attempt to influence decisions by capturing policy processes and outcomes. This is a sort of 'institutional corruption' variously described as 'market-driven politics' or as 'post-democracy' (Leys, 2001; Crouch, 2004). The lobbyists make sure to secure and capitalize on favourable assumptions by offering incentives in the form of travel and hospitality, paid and unpaid advisory positions, and - the big prize - board memberships once politicians and senior civil servants leave public service. This phenomenon is so well known that a term has been invented to describe it - the revolving door. Institutional corruption is not the term used by theorists of governance though they do discuss the rise of the 'unelected' in policy making - a development of which writers such as Vibert (2006) approve. We see this as symptomatic of what Janine Wedel has called 'flex networks', a new development whereby the entanglement of public and private sectors leads to the breakdown of notions of ethical behaviour and the collapse of the ability to police such standards as exist (Wedel, 2009).

\section{Strategy: Corporate capture}

In order to deal with the stratification of decision making the largest corporations organize at each venue of decision making. They maintain or fund a complex and ever changing network of lobby groups, policy planning organizations, front groups, institutes, science based initiatives and think tanks. We have included a number of think tanks and science oriented organizations which may appear on the surface to be independent but in reality are vehicles for corporate influence, being funded mostly or exclusively by big business and performing varying roles for the corporations.

These can be thought of as both vertically and horizontally differentiated and an indicative range is illustrated in Table 1 . In reality the picture is much more complex in that there are many more organizations than we show and that many have more than one function or operate at more than one level of governance. For example, though we only show it at the 'Scottish' level, the Scotch Whisky Association is a powerful actor at the UK and EU levels as well. The table reveals firstly that corporate interests are organized at every level of governance in a myriad of ways.

The targeting of decision making in Scotland is often coordinated by Scottish based or at least Scottish titled groups and the same goes for the UK (Statal) level and on up to the global forums of governance. 
Table 1 Vertical and horizontal corporate avenues of influence

\begin{tabular}{|c|c|c|c|c|}
\hline $\begin{array}{l}\text { Level of } \\
\text { governance / } \\
\text { Arena of focus }\end{array}$ & Scottish & $U K$ & $E U$ & Global \\
\hline $\begin{array}{l}\text { Parliamentary } \\
\text { groups }\end{array}$ & $\begin{array}{l}\text { Scottish } \\
\text { Parliament } \\
\text { and Business } \\
\text { Exchange } \\
\text { Cross Party } \\
\text { Groups }\end{array}$ & $\begin{array}{l}\text { All-Party } \\
\text { Whisky and } \\
\text { Spirits Group } \\
\text { Industry and } \\
\text { Parliament } \\
\text { Trust }\end{array}$ & $\begin{array}{l}\text { European } \\
\text { Parliament } \\
\text { policy discussion } \\
\text { groups }\end{array}$ & $\mathrm{n} / \mathrm{a}$ \\
\hline $\begin{array}{l}\text { Trade } \\
\text { association }\end{array}$ & $\begin{array}{l}\text { Scotch } \\
\text { Whisky } \\
\text { Association }\end{array}$ & $\begin{array}{l}\text { Scotch } \\
\text { Whisky } \\
\text { Association }\end{array}$ & $\begin{array}{l}\text { European } \\
\text { Association of } \\
\text { Communication } \\
\text { Agencies }\end{array}$ & $\begin{array}{l}\text { Snack Food } \\
\text { Association }\end{array}$ \\
\hline & $\begin{array}{l}\text { Scottish } \\
\text { Retail } \\
\text { Consortium }\end{array}$ & $\begin{array}{l}\text { Advertising } \\
\text { Association }\end{array}$ & $\begin{array}{l}\text { Brewers of } \\
\text { Europe }\end{array}$ & $\begin{array}{l}\text { Global } \\
\text { Alcohol } \\
\text { Producers } \\
\text { Group }\end{array}$ \\
\hline $\begin{array}{l}\text { Classwide } \\
\text { lobby group }\end{array}$ & Scottish CBI & $\begin{array}{l}\text { Confederation } \\
\text { of British } \\
\text { Industry }\end{array}$ & $\begin{array}{l}\text { European } \\
\text { Roundtable of } \\
\text { Industrialists }\end{array}$ & $\begin{array}{l}\text { World } \\
\text { Business } \\
\text { Council for } \\
\text { Sustainable } \\
\text { Development }\end{array}$ \\
\hline Lobby groups & $\begin{array}{l}\text { Scottish Beer } \\
\text { and Pub } \\
\text { Association }\end{array}$ & $\begin{array}{l}\text { The Portman } \\
\text { Group }\end{array}$ & $\begin{array}{l}\text { European Food } \\
\text { Information } \\
\text { Council }\end{array}$ & $\begin{array}{l}\text { International } \\
\text { Food } \\
\text { Information } \\
\text { Council }\end{array}$ \\
\hline $\begin{array}{l}\text { Science } \\
\text { related }\end{array}$ & $\mathrm{n} / \mathrm{a}$ & $\begin{array}{l}\text { British } \\
\text { Nutrition } \\
\text { Foundation }\end{array}$ & $\begin{array}{l}\text { Weinberg } \\
\text { Group } \\
\text { Landmark } \\
\text { Europe }\end{array}$ & $\begin{array}{l}\text { International } \\
\text { Life Sciences } \\
\text { Institute } \\
\text { World Sugar } \\
\text { Research } \\
\text { Organization }\end{array}$ \\
\hline Think tank & $\begin{array}{l}\text { International } \\
\text { Futures } \\
\text { Forum }\end{array}$ & $\begin{array}{l}\text { Policy } \\
\text { Exchange }\end{array}$ & $\begin{array}{l}\text { Centre for the } \\
\text { New Europe }\end{array}$ & $\begin{array}{l}\text { ICAP } \\
\text { (International } \\
\text { Center for } \\
\text { Alcohol } \\
\text { Policies) }\end{array}$ \\
\hline
\end{tabular}


Table 1 (Continued)

\begin{tabular}{lllll}
\hline Level of & Scottish & UK & Global \\
governance/ & & & \\
Arena of focus & & &
\end{tabular}

\begin{tabular}{llll}
\hline & $\begin{array}{l}\text { Scottish } \\
\text { Council } \\
\text { Foundation }\end{array}$ & $\begin{array}{l}\text { Adam Smith } \\
\text { Institute }\end{array}$ & \\
& & \\
& $\begin{array}{l}\text { Democracy } \\
\text { Institute }\end{array}$ & \\
Sedia & $\mathrm{n} / \mathrm{a}$ & $\begin{array}{l}\text { Science Media } \\
\text { Centre } \\
\text { influence }\end{array}$ & Social Issues \\
& Research \\
& Centre & \\
& & \\
& & & \\
& & & \\
& & Erinkaware & European \\
& Alcohol and \\
& Health Forum
\end{tabular}

Note: All these bodies are (at least in part) funded or supported by the alcohol and fast food/obesity industry. Supporting documentation on each of these organizations as avenues of corporate influence (as opposed to disinterested actors) is available at www.powerbase.info

Horizontal integration and differentiation is shown by the spread of organizations with differing functions either representing differing corporations or industrial sectors or orienting towards varying arenas in society whether that be the parliamentary arena or science, the media, civil society etc. The organizations are also variegated by type including think tanks and trade associations, science related and front groups as well as partnership organizations. Table 1 also indicates that not all possible arenas are targeted. For example there are no parliamentary focused bodies at the global level, since there is no global parliament.

\section{Direct and indirect methods}

Lobbyists are ultimately interested in changing or maintaining policies. But that does not mean that they therefore only target the policy community for capture. On the contrary it is important to note that lobbyists operate to capture a wide range of arenas in addition which they hope and intend to use to capture policy. For our purposes we can examine science capture, civil society capture and media capture, though we could equally examine the capture of the legal process or education or other areas of society. Each of these 
has as its ultimate aim the capture of decision making. Direct policy capture is an important strategy, but indirect methods are also increasingly of use.

\section{Science capture}

Capturing scientific expertise is a key objective for lobbyists. The tobacco industry successfully muddied the waters about the health effects of tobacco for thirty years (Holden and Lee, 2009). Similar tactics are currently being used by the food and alcohol industries. Attempts to capture science by corporate interests in general are increasingly well documented (Krimsky, 1995; Mooney, 2006; McGarrity and Wagner, 2008; Michaels, 2008; Wiist, 2010). Such strategies involve more than 'spinning' science and encompass very wide-ranging attempts to skew the scientific evidence base and to manage the whole scientific enterprise. McGarrity and Wagner (2008: 10) describe the 'tools for bending science' as 'shaping, hiding, attacking, harassing, packaging and spinning' - tools that encompass the entire range of scientific process. Given the extensive literature in this area we do not go in to more detail on this here save to indicate that science as an activity crosses all three spheres of society outlined in Figure 1 in the introduction to this volume (Miller and Mooney, 2010), playing a key role inside the corporation, in civil society and in government.

If the science cannot be captured, the strategy is likely to be to create uncertainty to block meaningful policy change (Michaels, 2008). The point is that this is done as a means of influencing opinion and decision making across varying domains. Thus while policy may be the ultimate goal, preparing and defending a particular line using managed science can also affect media and public discussion and constrain the views and activities of civil society groups. Alternatively the product of 'bent' science can also be used by those elements of civil society used by the corporations to dominate the information environment.

\section{Civil society capture}

Capturing civil society is also part of corporate strategy. Separate from the market and the state, civil society includes charities, non-governmental 
organizations, trades unions, social movements, business associations and other groups (Centre for Civil Society, n.d.). While there is some debate about the precise limits of civil society (Edwards, 2005) we do not include bodies that are under the direct and open control of business, only those that are not, or claim not to be, under direct control. This is obviously not a matter of a clear dividing line but rather a moveable scale. This is important since one of the oldest corporate techniques is the creation of front groups - organizations claiming to be independent but actually controlled by corporations (Miller and Dinan, 2008). In practice much work on civil society leaves out the inconvenient case of corporate involvement in civil society.

The use of fake citizen groups - so-called 'astroturf organizations - is a key technique. These appear to be genuine charitable organizations set up by or in the interests of ordinary citizens. In reality they may exist solely or mainly for particular policy purposes. One such organization unearthed in our research was The Obesity Awareness and Solutions Trust:

The Obesity Awareness and Solutions Trust (Toast) boasted about causing an influential parliamentary inquiry into obesity while failing to declare its financial links to the weight-loss industry. Toast also used a Westminster lobbying firm to 'acquire' a large group of 'parliamentary patrons'. (Gillard, 2008)

Some of the patrons claimed that they had not been informed about the links with the diet firm:

Conservative MP David Amess, a key Toast supporter, lobbied colleagues on the Health Select Committee to hold an inquiry into obesity ... Mr Amess admits he had not carried out checks before acting for Toast and says he feels he was 'conned'. (Gillard, 2008)

TOAST was formally wound up in 2008, but is not an isolated example in the sense that it was part of a continuing dense network of organizations attempting to play a role in obesity policy. Not all of these are 'front' groups in the same way as TOAST, largely because each organization has its own modus operandi and overall function.

For example three of TOAST's parliamentary patrons were members of the Health Select Committee when it investigated obesity in 2004 and most of the rest were involved in cross-party groups on health related issues, many of which are funded by the corporations. These 
in turn have multiple connections to the corporations. Tracing from TOAST we find that its PR company, the Whitehouse Consultancy, has a range of other obesity related companies amongst its clients. Its director Christopher Whitehouse is also a director of a company called Westminster Forum Projects which runs the Westminster Food and Nutrition Forum, a body which also boasts a long list of parliamentary patrons including many of those associated with TOAST. A similar list of patrons is to be found at the Associate Parliamentary Health Group which is run by a further lobbying firm called Policy Connect. Baroness Julia Cumberledge, one of the patrons of the APHG, herself runs a lobby firm (Cumberledge Connections) which for a time was controversially based in her office in the House of Lords (Hencke and Evans, 2009). Among the corporations funding the APHG are Abbott Laboratories, Alliance Boots, Astra Zeneca, BUPA, GlaxoSmithKline, Pfizer, SanofiAventis, Schering Plough and Wyeth (Associate Parliamentary Health Group, 2010). These interlocking connections - which we only hint at here - show the myriad ways in which corporate interests attempt to dominate and colonize the information environment around the legislature specifically.

Other seemingly disinterested groupings in civil society can have similar links, often undisclosed. For example the rise of think tanks is a key way in which mostly corporate money (in the UK) is channelled into apparently disinterested or non-partisan organizations that are said to provide a bridge between knowledge and policy. There is not space to look at this in detail here (though see Ruane, this volume for a discussion), but it can be noted that seen from the perspective of the corporations, the distinction between a front group, a policy discussion forum and a think tank is more a question of targeting and strategy than location at some point on the scale of 'independence'. Take the example of Pfizer, the US based pharmaceutical corporation that funds the APHG. Pfizer has made it a priority to fund and to create think tanks all over the world. Former Reagan administration official, Catherine Windels, was in charge of 'Worldwide Policy Mobilization'. In which role she reportedly 'helped create new think tanks and networks of think tanks in Europe, Canada, Africa and Asia, as well as ... in the US' (cited in Powerbase, 2010).

By these means corporations are able to populate the information environment with a wide variety of seemingly independent and unconnected organizations that have the advantage of uttering messages consonant with corporate interests. Of course the information environment is not the only game in town. 


\section{Media capture}

The capture of the media is important as it provides an opportunity to connect with popular opinion as well as elite opinion and can help in attempts to target and destroy critics. This is important because the media can play a direct role in lobbying and policy making, while also mediating popular concerns.

The full range of mechanisms by which the media are 'captured' by the corporations is well known in academic work on media institutions and processes. Any such account includes the influence of media ownership, advertising, public relations and spin, attacking critics and at least in some models - the question of ideology. We do not dissent for these models which - Marxist or liberal - are largely agreed on the mechanisms, if varying in their emphasis and theoretical frameworks (McChesney, 2008). To those models we would add the use and role of the media in securing policy capture, and in particular the sophisticated use of seemingly independent organizations which perform a public relations role for industry at one remove. This is a neglected field in media studies, as well as in social policy (Miller and Dinan, 2009). Capturing the media is done by both traditional means such as the use of apparently independent organizations set up to target the media as well as newer attempts to directly take over the means of communication.

One example of the former is the Social Issues Research Centre (SIRC), an 'independent, non-profit organisation' that says it carries out 'balanced, calm and thoughtful' research on lifestyle issues such as drinking, diet, and pharmaceuticals. However, it may be perceived that the company acts more like a public relations agency for the corporations that fund its activities. These include Diageo, Flora, CocaCola, GlaxoSmithKline, and Roche, among others. Although SIRC does publish this partial list of funders, it is not immediately apparent which company has sponsored which study and in some instances this information is not included in media reports (cited in Miller and De Andrade, 2010).

SIRC is sceptical that there is such a thing as an obesity 'epidemic', which fits with the interests of funders such as Coca-Cola, Cadbury Schweppes, Masterfoods, and the Sugar Bureau. It has coined the term 'riskfactorphobia' to suggest that we are too averse to risk, which fits the interests of the food companies as well as the raft of alcohol firms for which SIRC works. None of the reports mentioned in the foregoing 
paragraph contain information about the source of funding, so it is difficult to tell how 'clients' feed into particular activities. In some cases SIRC does say which corporation has sponsored its reports. Tio Pepe, a drinks company, funded one on dinner parties; and pub chain owner Greene King on 'the local' (Miller and De Andrade, 2010).

Although SIRC's publicity material regularly uses the term 'social scientists' to refer to its own staff, it uses the same personnel and office as a commercial market research company, MCM Research. SIRC's codirectors, Peter Marsh and Kate Fox, work for both organizations. The MCM website used to ask: 'Do your PR initiatives sometimes look too much like PR initiatives? MCM conducts social/psychological research on the positive aspects of your business. The results do not read like PR literature, or like market research data. Our reports are credible, interesting and entertaining in their own right. This is why they capture the imagination of the media and your customers' (cited in Ferriman, 1999).

Recently, however, MCM has taken a lower profile. Its website now redirects to that of SIRC, and visitors are informed that the centre 'has now taken over the task of hosting and publishing reports and materials conducted under the MCM Research name' (cited in Miller and De Andrade, 2010).

Still, SIRC is taken seriously by some in government. It was recently commissioned to produce two independent reviews for an investigation by the Department for Children, Schools and Families of the commercialization of childhood. The reports, published in late 2009, oppose a public health approach that is based on population level measures, including the restriction of advertising or marketing. The conclusion that SIRC reached is that 'the issues involved are very much more complex' - a position consistent with that advanced by elements of the food and advertising industries (cited in Miller and De Andrade, 2010). This nicely illustrates the multiple role of organizations like SIRC: to become trusted sources for both media and policy.

It is important for the corporations to try to exert maximum message control while at the same time appearing to be subject to the vagaries of 'independent' media. As a result, in recent years the media and the internet have become important resources in lobbying campaigns. So much so that one US PR and lobbying firm has invented what has been called 'journo-lobbying' (Confessore, 2003; Miller and Dinan, 2008). One pioneering example is Tech Central Station which appears at first glance to be a kind of think tank cum internet magazine. Look a little deeper and it is apparent that TCS has 'taken aggressive 
positions on one side or another of intra-industry debates, rather like a corporate lobbyist' (Confessore, 2003).

'But', writes Nicholas Confessore, 'TCS doesn't just act like a lobbying shop. It's actually published by one - the DCI Group, a prominent Washington "public affairs" firm specializing in P.R., lobbying, and so-called "Astroturf". Clients have included McDonald's and Coca-Cola. The two organizations 'share most of the same owners, some staff, and even the same suite of offices in downtown Washington, a block off K Street . . . TCS not only runs the sponsors' banner ads; its contributors aggressively defend those firms' policy positions, on TCS and elsewhere' (Confessore, 2003).

Journo-lobbying is 'an innovation', notes Confessore

driven primarily by the influence industry. Lobbying firms that once specialized in gaining person-to-person access to key decision-makers have branched out. The new game is to dominate the entire intellectual environment in which officials make policy decisions, which means funding everything from think tanks to issue ads to phony grassroots pressure groups. But the institution that most affects the intellectual atmosphere in Washington, the media, has also proven the hardest for $\mathrm{K}$ Street to influence - until now. (Confessore, 2003)

This blurring of the line between journalism and lobbying is central to the contemporary use of the traditional media, but is obviously given a significant boost by the birth of the internet and especially Web 2.0 techniques.

\section{Policy capture}

We have suggested that the attempt to capture varying arenas of debate and decision can be analysed separately as we have tried to do here. But, of course, as we noted at the beginning, separating them, while analytically useful is by no means a tidy process. The very extensive engagement of the corporations with science is intended to enable them to use science as a resource in policy capture. The media are engaged with to protect the flank and to push forward particular wider interests or attack critics. Civil society is a means for the corporations to see off the opposition of activist groups and the trades unions. 
Policy capture of one sort or another is the ultimate aim of all the strategies outlined here and many others. As we have noted this can be done directly or indirectly. The most obvious way in which corporations directly pursue their interests is via interaction with policy makers either on their own account or via heavyweight 'trade associations'. These are largely sectoral associations such as the Food and Drink Federation, which represents most UK active firms engaged in the manufacture and sale of food and beverages. The FDF hired lobbying and PR firm Bell Pottinger in early 2006 to add to their other PR efforts 'focusing initially on vending, food labelling and advertising to children'. 'The temperature has risen', said Bell Pottinger director Kevin Read. 'Food and drink is now a major social issue. People talk about it in the pub.' FDF deputy director-general, Martin Paterson, added 'We're cranking up PR activity,' he says. 'Our arguments need to be heard' (Quainton, 2006).

Only days later the industry scored a victory on salt when the Food Standards Agency revised its own targets upwards. Although it had 'previously declared a wish to cut the overall daily salt intake from $10 \mathrm{~g}$ to $6 \mathrm{~g}$ per person within four years, campaign groups argued that the revised targets would effectively raise recommended salt consumption to $8 \mathrm{~g}$ a day'. The new targets were quickly welcomed by the FDF, as 'more realistic'. Consensus Action on Salt and Health accused the FSA of bowing to the industry's 'purely commercial interests' after an intense lobbying campaign (Rowan, 2006). Such decisions reflect the difficult balancing act of an organization set up to 'restore consumer confidence' a phrase which has a dual meaning. For the public it was supposed to mean a new agency on the side of the consumer. For the government and industry, meanwhile, it also means that the agency will perform a strategic role in managing public perceptions. This tightrope is mirrored inside the agency where many of the staff have a commitment to public health and independence from government, while at the same time the people put in charge of the agency are strongly linked to industry. Deirdre Hutton, the chair of the FSA from July 2005, had shares in GlaxoSmithKline, Tesco and Unilever. Her replacement, Jeff Rooker, a Labour member of the House of Lords stepped down as the president of the Royal Association for British Dairy Farmers, to take up the FSA job. Eight of the thirteen board members also have some connection to the food or farming industries. Currently (in mid 2010) it has not a single board member with any experience in a public interest campaigning organization (Food Standards Agency, 2010). This account of regulatory agencies suggests that the corporate strategy to attempt to capture policy may often be successful at both a structural and practical level. 


\section{Partnership governance in the UK}

The involvement of unelected partners in the delivery of policy is an increasing facet of social policy at all levels of governance. We take two UK examples below, but there are similar experiences elsewhere. A 2004 Australian study examined a partnership between Alcohol Education Australia and the alcohol industry: the findings upheld the argument that such partnerships are more beneficial to the corporate sponsor than to any public health objectives. It also found that maintaining an 'uncompromising public health orientation' was difficult when in partnership with the alcohol industry (Munro, 2004). In Scotland the implementation of the Partnership Agreement between the alcohol industry and the Scottish government was led by an official seconded in to the civil service from his day job as a lobbyist for Diageo (Smith, 2007). Alcohol policy in the EU is taken forward by the European Alcohol and Health Forum, composed of NGOs and the alcohol, advertising and sponsorship industries, though dominated by commercial interests (Eurocare, 2007). It was modelled on the obesity policy vehicle the EU Platform on Diet, Physical Activity and Health, whose membership consists of industry, public health NGOs and the European Commission and again is dominated by corporate interests. At the global level a similar picture is evident with the UN Global Compact being a partnership scheme between the United Nations and leading transnational corporations.

\section{Obesity and Change4Life}

Change4Life, launched in January 2009, is the Department of Health $(\mathrm{DoH})$ anti-obesity marketing campaign. ${ }^{1}$ Described as an 'evidence based' marketing programme it will help 'parents in making changes to their children's diet and levels of physical activity' (Department of Health, 2008a: ix).

Change4Life had been on the agenda since the government's Choosing Health White Paper published in 2004 (Department of Health, 2004). The paper called for the development of a joint industry and government fund for promotional campaigns (Department of Health, 2004: 6). But, according to documents released under Freedom of Information legislation, six months before the Choosing Health paper was published a coalition of industry representatives approached the government with a blueprint for a campaign that resembled the Change4Life project (Advertising 
Association et al., 2004). In 2008 the coalition reported that over 100 companies coordinated by the Advertising Association's Business4Life group would put up an 'in-kind' contribution of $£ 200$ million 'media equivalent value' (Whitehall Pages, 2008). The government provided $£ 75$ million of real cash from the $£ 372$ million obesity budget (Department of Health, 2008).

All of the $£ 75$ million was paid to $M \& C$ Saatchi, which won the advertising contract to promote Change4Life (M\&C Saatchi, 2010). In addition an associated PR contract was awarded to Freud Communications. Both contracts revealed the myriad connections, conflicts of interest and permeability of the boundaries between the private and public sectors. The Saatchi contract decision was the responsibility of Andrew Brent, then director of marketing within the DoH. Previously a marketing executive with Boots and Burger King, Brent left the DoH after only five months to work for Business4Life member BSkyB. The DoH stated that Brent had taken the post on the understanding that he would run preparations for the anti-obesity campaign until he found a private sector job (Benady, 2008).

There are further overlaps at Freud Communications, whose clients include Mars, Nestlé and PepsiCo (all members of Business4Life) (Freud Communications, 2010). The ubiquitous Matthew Freud is sonin-law of Rupert Murdoch (Harris, 2008), whose BSkyB is both a Freud client and Business4Life member (Freud Communications, n.d.; Business4Life, n.d.). Other connections include Freud's Deputy Chairman, Lord (Philip) Gould of Brookwood, prominent architect of New Labour (Marriott, 2007). He is also an advisor to Freud client, PepsiCo, sitting alongside former Health Secretary, Alan Milburn MP (BBC News, 2006), on its nutritional board (Register of Lords' Interests, 2010).

Such connections raised eyebrows when Freud won the contract as two other agencies pitching for the contract were told they were eliminated from the running because of the fast food clients on their books (Cartnell, 2008; Farey-Jones, 2009). In 2009 Freud bought a 3.3\% share in M\&C Saatchi (Griffin, 2009).

But what of the 'in-kind' corporate contribution? This support has manifested itself in a variety of forms, with Kellogg's expanding its Breakfast Clubs programme under the title of Breakfast 4 Life (Business4Life, n.d.) while, at the same time, encouraging children to eat Coco Pops (containing $30 \mathrm{~g}$ of sugar per $100 \mathrm{~g}$ serving) for breakfast and after school (Hickman, 2010). Meanwhile PepsiCo continues to promote its main fizzy drink (41 g of sugar per $340 \mathrm{~g}$ serving; eConsultant, n.d.) 
by associating it with the very football stars it uses to endorse the Change4Life campaign (PepsiCo, 2010a, 2010b). It is not clear, in the end, if the companies are promoting the Change4Life message or if Change4Life is promoting brand awareness for the food companies.

A key criticism of Change4Life is that there are no obvious criteria on which corporations could be excluded, even on the basis of bad practice. As Sustain spokesperson Jeanette Longfield commented, 'If you don't have any criteria for entry you completely debase the currency' (Cooper, 2008). Sustain supports the traffic light scheme on food labelling, arguing that it is preferred and understood by consumers. The food industry has a long history of undermining the traffic light scheme, winning victory in early 2010 (Hickman, 2010). The traffic light system is a voluntary UK food labelling code supported by the FSA. Levels of salt, sugars and fats are illustrated by traffic light colours (FSA, n.d.). Industry involvement in Change4Life provides a means to appeal to policy makers and contributes to brand awareness. Both help avoid binding regulation.

\section{Drinkaware Trust}

A similar picture is evident in the development of the Drinkaware Trust, which says that it 'promotes responsible drinking' and attempts to 'reduce alcohol misuse and minimise alcohol-related harm' (Drinkaware Trust, 2010a). The Trust was designed to provide a platform for alcohol education that was independent from the alcohol industry. Yet today it is based inside the headquarters of the Portman Group, the big alcohol lobby group (Harkins, 2010).

The Trust was established in late 2006 as part of the 2004 Alcohol Strategy for England (Cabinet Office, 2004) which advocated establishing a new independent national fund to support a reduction in alcohol harm. The Portman Group was against this and keen to run the fund itself (Baggott, 2006). Negotiations between industry and government resulted in the compromise that the Portman Group's charitable activities, which since 2004 had been conducted through their Drinkaware website, would be rebranded and given greater independence (Scottish Government, 2006).

The Trust is funded entirely by the alcohol industry (including several supermarkets). The industry pledged an annual budget of at 
least $£ 5$ million by the Trust's third year. However, by their own account, between 2007 and 2009 the industry had contributed a total of $£ 2,690,176$ (Drinkaware Trust, 2010b). The funding shortfall is significant, especially when compared to the $£ 800$ million spent annually in the UK on promoting alcohol (Hastings and Angus, 2009), in a market worth around $£ 33.7$ billion in 2007 (Nielsen, 2008). Although, in June 2009, the Trust appointed Professor Paul Wallace (Professor of Primary Care at University College London, and a general medical practitioner) as its medical adviser, Drinkaware presents a view of alcohol and its abuse consistent with the alcohol industry's philosophy (Drinkaware Trust, 2009).

It focuses its prevention work on educational activities, an approach found consistently to be the least effective lever in controlling alcohol consumption and subsequent harm (Babor et al., 2003). This is as opposed to taking a population based approach and adopting tighter regulation of alcohol (Babor et al., 2003). The Trust shares the view of the alcohol industry that the majority of people drink responsibly (Drinkaware Trust, 2010c) - despite alarming increases in rates of alcohol related harm and figures that show alcohol related harm is not particular to certain groups, but evident across the board (Academy of Medical Sciences, 2004; Donaldson, 2008; Meier et al., 2009). In Scotland, for example, Nielson data show that if the Scottish population were to consume alcohol within the UK government guidelines, there would be a reduction of around a quarter of alcohol sales in Scotland (worth around £900 million) (Nielsen, 2008).

Educational campaigns have been found to be the least effective means of reducing alcohol related harm (Babor et al., 2003). Industryfunded campaigns have been found to be the least effective of all. When tobacco conglomerate Philip Morris designed and funded television campaigns in America to discourage youths from using tobacco, research found that their efforts may have actually encouraged children to smoke (Sebrie and Glantz, 2007; Wakefield et al., 2006). Independently funded campaigns, in contrast, were found to be more effective (Hyland et al., 2006; Warner, 2006).

Commenting on a 2009 Drinkaware campaign 'Why let good times go bad?' targeting binge drinkers aged 18-24, Don Shenker, chief executive of Alcohol Concern, stated: 'This new initiative appears to be yet another example of the drinks industry trying desperately to avoid mandatory legislation to pass on health information to consumers' (BBC News, 2009). 
Partnership working in other words promotes the erosion of barriers between government and the private sectors and makes the pursuit of social objectives harder because of the difficulty of taking decisions based on grounds of public health, social need or other social priorities.

\section{Conclusions}

Corporations seek to dominate the information and decision-making environment to pursue their interests. Such strategies are not always successful, but they certainly are comprehensively and consciously planned.

The examples we focus on here both relate to public health and the question of implementing public health measures. To be successful of course public health measures also need to be integrated with a range of other policy areas including education, and the provision of social services. But our wider point is that corporations use lobbying strategies in all areas of social policy. These, we argue are not add-ons or somehow separate from the rest of the activities of the corporations, but integrated and centrally directed, even if corporations themselves can be internally fractured over particular dimensions of strategy.

Public relations and lobbying activities have become more important in the neoliberal period as more space has been opened up for private sector engagement in policy creation and delivery. As a result we see qualitatively new sorts of governance emerge as the line between private and public sectors becomes more permeable. The advent of 'partnership' governance where public policy is not simply 'influenced' but is actually co-created and delivered by the private sector, indicates the increasingly shaky grip of concepts of governance developed before neoliberalism. This is why it is useful to turn to concepts such as that of the 'flex network' as developed by the anthropologist Janine Wedel (2009).

We argue that flex networks and partnership governance are a consequence of neoliberal modes of governance in social policy and that they indicate the central importance of corporate strategy in the creation and delivery of social policy. Our approach also insists that governance is a matter not simply of power or struggle but of communication, ideas and ideology. Lobbying and PR are fundamentally questions of communicative agency. Lobbying and PR then are newly and increasingly important topics for understanding the creation and delivery of social policy. 


\section{Note}

1. This section draws on research conducted for Powerbase (www.powerbase.info) - a collaborative project in which the authors are involved by Mary Craig, Kerri Park and in particular Kyle McCallum, whom we acknowledge.

\section{References}

Academy of Medical Sciences (2004) Calling Time: The Nation's Drinking as a Major Health Issue. London: Academy of Medical Sciences.

Advertising Association, British Hospitality Association, British Retail Consortium, Food and Drink Federation, Incorporated Society of British Advertisers, National Farmers Union (2004) 'Briefing Note 14 May 2004: Joint Multi-Media Consumer Information Programme on Food and Health', released under Freedom of Information Act, received 2 April 2009 [online]. [http://www.powerbase.info/images/9/98/14.05_briefing_note.word95.doc], accessed 5 April 2009.

Anderson, P. and Baumberg, B. (2006) 'Alcohol in Europe: A Report for the European Commission'. Institute of Alcohol Studies.

Associate Parliamentary Health Group (2010) 'Associate Members' [http:// www.healthinparliament.org.uk/associate_members.html], accessed 15 May 2010.

Babor, T. et al. (2003) Alcobol: No Ordinary Commodity. Research and Public Policy. Oxford: Oxford University Press.

Baggott, B. (2006) 'Alcobol Strategy and the Drinks Industry: A Partnership for Prevention? York: Joseph Rowntree Foundation. [http://www.jrf.org.uk/ publications/alcohol-strategy-and-drinks-industry-partnership-prevention], accessed 22 April 2009.

BBC News (2006) 'Profile: Alan Milburn' [http://news.bbc.co.uk/1/hi/uk_ politics/5356016.stm], accessed 8 May 2010.

BBC News (2009) 'Industry Drive to Curb Drinking', 15 July [http://news. bbc.co.uk/1/hi/health/8152721.stm], accessed 10 January 2010.

Beaglehole, R. and Bonita, R. (2009) 'Alcohol: A Global Health Priority', The Lancet 373(9682) (26 June): 2173-4. [http://www.thelancet.com/series/ alcohol-and-global-health], accessed 27 June 2009.

Benady, D. (2008) 'Pitfalls of Public Sector Marketing', Marketing Week 17 September [http://www.marketingweek.co.uk/home/pitfalls-of-publicsector-marketing/2062459.article], accessed 24 May 2009.

Brownell, K. D. and Warner, K. E. (2009) 'The Perils of Ignoring History: Big Tobacco Played Dirty and Millions Died. How Similar is Big Food?', The Milbank Quarterly 87(1): 259-94. 
Business4Life (n.d.) 'b4l in action' [http://www.business4life.co.uk/b4linaction/], accessed 22 April 2010.

Cabinet Office (2004) Alcohol Harm Reduction Strategy for England. Prime Minister's Strategy Unit. [http://www.cabinetoffice.gov.uk/media/cabinetoffice/strategy/assets/caboffce\%20alcoholhar.pdf\}, accessed 22 July 2009.

Cartnell, M. (2008) 'Freud Lands Anti-obesity Brief, PR Week 1 August [http://www.prweek.com/news/rss/835807/Freud-lands-anti-obesitybrief/], accessed 10 May 2010.

Centre for Civil Society (n.d.) 'What is Civil Society?' [http://www.lse.ac.uk/ collections/CCS/what_is_civil_society.htm], accessed 22 April 2010.

Confessore, N. (2003) 'Meet the Press: How James Glassman Reinvented Journalism - as Lobbying', Washington Monthly December [http://www. washingtonmonthly.com/features/2003/0312.confessore.html], accessed July 2008.

Cooper, B. (2008) 'Food Industry at Heart of New Anti-obesity Drive', Just Food 20 November [http://www.just-food.com/article.aspx?id=104522], accessed 23 March 2009.

Crouch, C. (2004) Post-Democracy. Cambridge: Polity Press.

Department of Health (2004) Choosing Health: Making Healthy Choices Easier. London: The Stationery Office.

Department of Health (2008) Healthy Weight, Healthy Lives: A CrossGovernment Strategy for England. Cross-Government Obesity Unit, Department of Health. [http://www.dh.gov.uk/en/Publicationsandstatistics/ Publications/PublicationsPolicyAndGuidance/DH_082378], accessed 23 March 2010.

Donaldson, L. (2008) '150 Years of the Annual Report of the Chief Medical Officer: On the State of Public Health 2008' [www.dh.gov.uk/prod_consum_dh/groups/dh_digitalassets/documents/digitalasset/dh_096231. pdfł, accessed 22 March 2010.

Drinkaware Trust (2009) 'Drinkaware Appoints Chief Medical Adviser' [http://www.drinkaware.co.uk/media/press-releases/2009-press-releasearchive/drinkaware-appoints-chief-medical-adviser], accessed 15 February 2010.

Drinkaware Trust (2010a) 'About Us' [http://www.drinkaware.co.uk/about us], accessed 15 February 2010.

Drinkaware Trust (2010b) 'Donations to Date', 2007-2009 [http://www. drinkaware.co.uk/_data/assets/pdf_file/0014/11912/fundersanddonations2007-09.pdf], accessed 15 February 2010.

Drinkaware Trust (2010c) 'Alcohol in the UK' [http://www.drinkaware. co.uk/alcohol-and-you/alcohol-in-the-uk], accessed 15 February 2010.

eConsultant (n.d.) 'Ask the eConsultant' [http://www.econsultant.com/articles/sugar-content-of-cola-pop-soda-drinks.html], accessed 7 May 2010.

Edwards, M. (2005) 'Civil Society', in The Encyclopaedia of Informal Education [www.infed.org/association/civil_society.htm], accessed 12 May 2010. 
Eurocare (2007) 'Eurocare and Members to Join the EC's Alcohol and Health Forum', Press Release, 7 June [http://www.eurocare.org/press/eurocare_ press_releases/eurocare_and_members_to_join_the_ec_s_alcohol_and_ health_forum], accessed 3 July 2009.

Farey-Jones, D. (2009) 'Matthew Freud Takes Stake in M\&C Saatchi after Share Price Drop', Brand Republic News Release, 26 February, Media Week [http://www.mediaweek.co.uk/news/883946/Matthew-Freudtakes-stake-M-C-Saatchi-share-price-drop/], accessed 22 April 2009.

Farnsworth, K. (2004) Corporate Power and Social Policy in a Global Economy. Bristol: Policy Press.

Farnsworth, K. (2006) 'Capital to the Rescue? New Labour's Business Solutions to Old Welfare Problems', Critical Social Policy 26(4): $817-42$.

Farnsworth, K. and Holden, C. (2006) 'The Business-Social Policy Nexus: Corporate Power and Corporate Inputs into Social Policy', Journal of Social Policy 35(3): 473-94.

Ferriman, A. (1999) 'An End to Health Scares?', British Medical Journal 319: 716. [http://www.bmj.com/cgi/content/full/319/7211/716?ijKey=d05 bd96bb40a116823f810f8cdc39a5b1d1e2f10\&keytype2=tf_ipsecsha], accessed 1 May 2010.

Food Standards Agency (FSA) (n.d.) 'Traffic Light Labelling' [http://www. eatwell.gov.uk/foodlabels/trafficlights/], accessed 10 May 2010.

Food Standards Agency (2010) 'Our Board' [http://www.foodstandards.gov. uk/aboutus/ourboard/], accessed 10 May 2010.

Freud Communications (2010) 'Our Clients' [http://www.freud.com/], accessed 23 March 2010.

Gillard, M. (2008) 'MPs "Conned" Over Obesity Charity that Was Front for Diet Firm Trust that Used Public Cash to Influence the War on Fat is to Close after Revealing Links with Weight-loss Company', Independent on Sunday 20 January [http://www.independent.co.uk/news/uk/politics/ mps-conned-over-obesity-charity-that-was-front-for-diet-firm-771266. html], accessed 10 April 2010.

Griffin, K. (2009) 'Matthew Freud Buys Stake in M\&C Saatchi', The Telegraph 25 February [http://www.telegraph.co.uk/finance/newsbysector/mediatechnologyandtelecoms/media/4802011/Matthew-Freud-buys-stakein-MandC-Saatchi.html], accessed 10 May 2010.

Habermas, J. (1984) Reason and the Rationalization of Society, Vol. 1 of The Theory of Communicative Action, English trans. T. McCarthy. Boston: Beacon Press. (Originally published in German in 1981.)

Habermas, J. (1987) Lifeworld and System: A Critique of Functionalist Reason, Vol. 2 of The Theory of Communicative Action, English trans. T. McCarthy. Boston: Beacon Press. (Originally published in German in 1981.) 
Harkins, C. (2010) 'The Portman Group', British Medical Journal 340: b5659 [http://www.bmj.com/cgi/content/full/340/jan20_1/b5659], accessed 20 January 2010.

Harris, J. (2008) 'Inside the Court of London's Golden Couple', The Guardian 13 November [http://www.guardian.co.uk/politics/2008/nov/13/elisabeth-murdoch-matthew-freud-politics], accessed 10 May 2010.

Hastings, G. and Angus, K. (2009) 'Under the Influence: The Damaging Effects of Alcohol Marketing on Young People', British Medical Journal report [http://www.bma.org.uk/health_promotion_ethics/alcohol/undertheinfluence.jsp], accessed 20 January 2010.

Hawkes, C. (2006) 'Uneven Dietary Development: Linking the Policies and Processes of Globalization with the Nutrition Transition, Obesity and Diet-related Chronic Diseases', Globalization and Health 2(4) [http:// www.globalizationandhealth.com/content/2/1/4].

Hencke, D. and Evans, R. (2009) 'Tory Peer Accused of Misusing Lords to Boost her own Firm: Baroness Admits Listing of Interests Not "Punctilious". Pressure Group Spinwatch Lodges Complaint', The Guardian 29 January [http://www.guardian.co.uk/politics/2009/jan/28/conservativepeer-lady-cumberlege-finances], accessed 23 March 2010.

Hickman, M. (2010) 'Parents Furious over "Hypocrisy" of Cereal Ad: Kellogg's Accused of Pushing Coco Pops While Backing Obesity Campaign', Independent 1 February [http://www.independent.co.uk/life-style/ health-and-families/health-news/parents-furious-over-hypocrisy-ofcereal-ad-1885164.html], accessed 2 February 2010.

Holden, C. and Lee, K. (2009) 'Corporate Power and Social Policy: The Political Economy of the Transnational Tobacco Companies', Global Social Policy 9: 328-5.

Hyland, A., Wakefield, M., Higbee, C., Szczypka, G. and Cummings, K. M. (2006) 'Anti-Tobacco Television Advertising and Indicators of Smoking Cessation in Adults: A Cohort Study', Health Education Research 21(3): 348-54.

Kooiman, J. (1999) Modern Governance. London: SAGE.

Krimsky, S. (1995) Science in the Private Interest. New York: Rowman and Littlefield.

Leys, C. (2001) Market-driven Politics: Neoliberal Democracy and the Public Interest. London: Verso.

M\&C Saatchi (2010) '75m DoH Anti-Obesity Account' [http://www. mcsaatchi.com/news_article.php?id=162].

McChesney, R. W. (2008) The Political Economy of Media: Enduring Issues, Emerging Dilemmas. New York: Monthly Review Press.

McGarrity, T. and Wagner, W. (2008) Bending Science: How Special Interests Corrupt Public Health Research. Cambridge, MA: Harvard University Press. 
Marriott, H. (2007) 'Philip Gould Takes Freuds Position', PR Week 17 January [http://www.prweek.com/news/rss/626648/Philip-Gould-takesFreuds-position/], accessed 4 May 2010.

Meier, P., Purshouse, R., Meng, Y., Rafia, R. and Brennan, A. (2009) 'Modelbased Appraisal of Alcohol Minimum Pricing and Off-Licensed Trade Discount Bans in Scotland: A Scottish Adaptation of the Sheffield Alcohol Policy', School of Health and Related Research, University of Sheffield. [www.scotland.gov.uk/Publications/2009/09/24131201/0], accessed 19 November 2009.

Michaels, D. (2008) Doubt is their Product: How Industry's Assault on Science Threatens Your Health. Oxford: Oxford University Press.

Miller, D. and De Andrade, M. (2010) 'Independent Research Body or PR Agency for Corporations? The Social Issues Research Centre', British Medical Journal 340: c484 [http://www.bmj.com/cgi/content/full/bmj.c484?i jkey $=1$ anjS6jf2p2ikRP\&keytype $=$ ref\#REF181, accessed 1 May 2010.

Miller, D. and Dinan, W. (2008) A Century of Spin. London: Pluto.

Miller, D. and Dinan, W. (2009) 'Journalism, Public Relations and Spin', pp. 250-64 in K. Wahl-Jorgensen and T. Hanitzsch (eds) Handbook of Journalism Studies. New York: Routledge.

Miller, D. and Mooney, G. (2010) 'Introduction to the Themed Issue. Corporate Power: Agency, Communication, Influence and Social Policy', Critical Social Policy 30(4).

Mirowski, P. and Plehwe, D. (eds) (2009) The Road from Mont Pelerin: The Making of the Neoliberal Thought Collective. Cambridge, MA: Harvard University Press.

Mooney, C. (2006) The Republican War on Science. New York: Basic Books.

Munro, G. (2004) 'An Addiction Agency's Collaboration with the Drinks Industry: Moo Joose as a Case Study', Addiction 99(11): 1370-4.

Nestle, M. (2003) Food Politics. Berkeley, CA: University of California Press.

Nicholson, D. (2009) NHS Chief Executive's Annual Report 2009. London: Department of Health. [http://www.dh.gov.uk/prod_consum_dh/ groups/dh_digitalassets/documents/digitalasset/dh_099700.pdf], accessed 23 March 2010.

Nielsen (2008) 'Range of Data on Alcohol Sales by Volume, Liquor Category, Trade Sector, Per Capita, Retail Sales Value, and the Price of Alcohol Per Unit / Per Litre', Scottish Government, 17 June [http://www.scotland. gov.uk/Topics/Health/health/Alcohol/resources/nielson-data], accessed 15 August 2009.

PepsiCo (2010a) 'Didier Drogba of Chelsea Promoting Pepsi Max' [http:// www.pepsi.co.uk/], accessed 22 April 2010.

PepsiCo (2010b) 'Frank Lampard, the Face of Pepsi's Play4Life Campaign' [http://www.pepsi.co.uk/], accessed 22 April 2010. 
Powerbase (2010) 'Catherine Windels' [http://www.powerbase.info/index. php? title=Catherine_Windels], accessed 12 May 2010.

Quainton, D. (2006) 'Analysis: Food Lobby Forced onto the Defensive', PR Week 9 March [http://www.prweek.com/uk/home/article/545452/], accessed 23 March 2006.

Register of Lords' Interests (2010) [http://www.parliament.the-stationeryoffice.co.uk/pa/ld/ldreg/reg10.htm], accessed 4 May 2010.

Rehm, J. et al. (2004) 'Alcohol Use', pp. 959-1108 in M. Ezzati, A. D. Lopez, A. Rodgers and C. J. L. Murray (eds) Comparative Quantification of Health Risks: Global and Regional Burden of Disease Attributable to Selected Major Risk Factors, Vol. 1. Geneva: World Health Organisation.

Rhem, J. et al. (2009) 'Global Burden of Disease and Injury and Economic Cost Attributable to Alcohol Use and Alcohol-Use Disorders', The Lancet 373(9682) (27 June): 2223-33 [http://www.thelancet.com/journals/lancet/article/PIIS0140-6736(09)60746-7/abstract], accessed 30 June 2009.

Rhodes, R. A. W. (2000) 'Governance and Public Administration', pp. 54-90 in J. Pierre (ed.) Debating Governance: Authority, Steering, and Democracy. Oxford: Oxford University Press.

Rowan, D. (2006) 'Who's Got the Muscle?', The Times 25 March [http://www. timesonline.co.uk/article/0,,8123-2100578,00.html], accessed 11 July 2007.

Ruane, S. (2010) 'Corporate and Political Strategy in Relation to the Private Finance Initiative in the UK', Critical Social Policy 30(4).

Scottish Government (2006) 'Drinkaware Memorandum of Understanding', Scottish Government Publications, 26 October [http://www.scotland. gov.uk/Publications/2006/10/23132143/1], accessed 19 November 2007.

Sebrie, E. M. and Glantz, S. A. (2007) 'Attempts to Undermine Tobacco Control: Tobacco Industry "Youth Smoking Prevention” Programs to Undermine Meaningful Tobacco Control in Latin America', American Journal of Public Health 97: 1357-67.

Smith, D. (2007) 'Letter from Deborah Smith, Head of Alcohol \& Drug Misuse, 31st August 2006, to John Drummond, Chief Executive of the Scottish Grocers Federation', obtained via Freedom of Information legislation, August.

Vibert, F. (2006) The Rise of the Unelected: Democracy and the New Separation of Powers. Cambridge: Cambridge University Press.

Wakefield, M. et al. (2006) 'Effect of Televised, Tobacco Company-funded Smoking Prevention Advertising on Youth Smoking-related Beliefs, Intentions, and Behavior', American Journal of Public Health 96(12): 2154-60.

Warner, K. E. (2006) 'Tobacco Policy Research: Insights and Contributions to Public Health Policy', pp. 3-86 in K. E. Warner (ed.) Tobacco Control Policy. San Francisco: Jossey-Bass.

Wedel, J. (2009) The Shadow Elite. New York: Basic Books. 
Whitehall Pages (2008) 'Change4Life: The Healthy Living Revolution Starts Here' [http://www.whitehallpages.net/modules.php?op=modload\&name $=$ News\&file $=$ article\&sid $=149246 \&$ topic $=163 \&$ newlang $=$ eng $]$, accessed 23 March 2009.

Wiist, W. (2010) The Bottom Line or Public Health: Tactics Corporations Use to Influence Health and Health Policy, and What We Can Do to Counter Them. New York: Oxford University Press.

World Health Organisation (WHO) (2004) 'Global Strategy on Diet, Physical Activity and Health'. Geneva: WHO. [http://www.who.int/dietphysicalactivity/goals/en/index.html], accessed 30 June 2009.

a David Miller is Professor of Sociology in the School of Applied Social Sciences at the University of Strathclyde. He is co-author (with Will Dinan) of A Century of Spin (Pluto, 2008) and co-editor (with Neil Davidson and Patricia McCafferty) of Neoliberal Scotland (Cambridge Scholars, 2010). Address: Department of Geography and Sociology, University of Strathclyde, Graham Hills Building, Richmond Street, Glasgow G1 1XN, Scotland. email: davidmiller@strath.ac.uk

a Claire Harkins is a Doctoral Candidate in the School of Applied Social Sciences at the University of Strathclyde. Her Doctoral research examines contemporary modes of governance, particularly in relation to alcohol and public health policy. She edits the Alcohol Portal at Powerbase (www.powerbase.info). 